\title{
A study on relationship between working capital and profitability
}

\author{
Hassan Ghodrati and Jaber Ghanbari*
}

Department of Management and Accounting, Kashan Branch, Islamic Azad University, Kashan, Iran

\begin{tabular}{|c|c|}
\hline CHRON I C LE & A B S T RA C T \\
\hline $\begin{array}{l}\text { Article history: } \\
\text { Received January 20, } 2014 \\
\text { Accepted } 5 \text { July 2014 } \\
\text { Available online } \\
\text { July } 142014 \\
\text { Keywords: } \\
\text { Investment } \\
\text { Profitability } \\
\text { Collecting receivable period } \\
\text { Cycle of cash conversion }\end{array}$ & $\begin{array}{l}\text { This paper studies the relationship between working capital management and profitability of } \\
\text { accepted corporations in Tehran Stock Exchange over the period 2008-2012. The study selected } \\
66 \text { firms as a statistical sample based on Cochran formula and simple random selection. In this } \\
\text { study, variables including the average period of collecting accordance, periods of circulation of } \\
\text { inventories, the average period of debt payment, and cycle of cash conversion on the factories } \\
\text { operating profits are studied. The research method is applied and collection of data is solidarity, } \\
\text { the Pierson and Regression solidarity are used. Results show that variables of capital } \\
\text { investment management and profitability were in opposite direction. If the period of collecting } \\
\text { accordance, period of debt payment, period of circulation of inventories and the cycle of cash } \\
\text { conversion increase, it decreases the period profitability and the manager can decrease the } \\
\text { period of debt payment, period of cash conversion to the least amount of positive value for } \\
\text { affiliate. }\end{array}$ \\
\hline
\end{tabular}

\section{Introduction}

The working capital management normally consists of planning, assets control and the present debts in a way that removes the risk of meeting short-term expectations and avoids excessive investment on these assets. Many of these researches emphasize that managers spend a remarkable time on daily grind including capital inflow decisions (Mehar, 2005; Enyi, 2005). One of the reasons is that present assets are short-term investment and changes to other forms, constantly. Maximizing the profit in the long term is one of the primary objectives of every firm but keeping the firm's liquidity must be considered as well. Taking profit and losing liquidity may always lead to major problems for the firms and a balance is required between these two items. Any firm may face recession and file bankruptcy if it does not consider liquidity and control well for a long time sustainable profitability. Therefore, capital inflow must be always considered. The firms can consider an optimum capital inflow to maximize their values. Abundance in stock increases the sales and reduces stock shortage risk. As a result, because of the product assessment quality before paying, the credit leads to rise in *Corresponding author.

E-mail addresses: Dr.ghodrati42@yahoo.com (J. Ghanbari) 
sale. Payable accounts are another capital inflows part. The possibility of quality assessment will be provided by postponing paying to suppliers. On the other hand, suppliers offer discount for advanced payments. Any delay in bill payment can cost, enormously. The time between raw material buying and debt collection is a typical approach to examine the capital in flow of cash conversion cycle. The longer this time is, the higher this investment will be. They will increase profits as it increases sale. The profits may decline if the cost of investment surpasses maintenance. The mentioned capital inflow, its elements and their influence on profits, highlight the role of profit management of capital inflow, in Tehran Stock Market.

\section{Literature Review}

Sayaduzzaman (2006) showed that the efficiency of working capital management of British American Tobacco Bangladesh Company Ltd. was highly satisfactory because of the positive cash inflows and planned approach in managing the major elements of working capital. He found that working capital management could help us maintain all around efficiency in operations. Eljelly (2004) examined the relationship between profitability and liquidity by using correlation and regression analyses and found that the cash conversion cycle was of more importance as a measure of liquidity than the current ratio that affects profitability. Raheman (2007) studied the effect of various variables of working capital management. He found that there was a strong negative relationship between variables of Working Capital Management and Profitability. He also determined that as the cash conversion cycle increases, it leads to decrease in profitability of the firm and managers could create a positive value for the shareholders by reducing the cash conversion cycle to a possible minimum level. Deloof (2003) surveyed on Belgian Firms to find out whether the working capital management could influence on profitability. He determined that most firms had a large amount of cash invested in working capital. It can be expected that the way in which working capital was managed, could have a significant impact on the profitability of those firms. Lazaridis and Tryfonidis (2006) investigated relationship between working capital management and corporate profitability of listed companies in the Athens Stock Exchange. The results of the article showed that there was a statistically significant relationship between profitability and cash conversion cycle.

Ganesand (2007) suggested that efficient working capital management could increase firms' free cash flow, which in turn increased the firms' growth opportunities and return to shareholders. Chowdhury and Amin (2007) investigated working capital management practices in Pharmaceutical firms listed in DSE and reported that among all the problems of financial management, the problems of working capital management had probably been recognized as the most crucial one. Shin and Soenen (1998) suggested that efficient working capital management was very important for creating value for the shareholders. They found a strong negative relationship between lengths of the firm's net trading cycle and its profitability. In addition, they also found that shorter net trade cycles were associated with higher risk adjusted stock returns.

Amit et al. (2005) in their study regarding the relationship between working capital and profitability of Indian pharmaceutical industry reported no definite relationship between liquidity and profitability. Vishanani and Shah (2007) studied the effect of working capital management policies on corporate performance of Indian consumer electronic industry. They reported that no established relationship between liquidity and profitability exist for the industry as a whole. However, various firms of the industry depicted various kinds of relationship between liquidity and profitability, although majority of the companies revealed positive association between liquidity and profitability. Raheman and Nasr (2007) reported a negative relationship between profitability and liquidity of firms. Ganesan (2007) studied working capital management efficiency in Telecommunication equipment industry and reported significant statistical evidence and negative relationship between profitability and liquidity. Lyroudi and Lazardis (2000) investigated the cash conversion cycle and liquidity position of the food industry in Greece. They reported significant 
positive relationship between cash conversion cycle and current ratio, quick ratio, receivables conversion period and inventory conversion period and negative relationship between cash conversion cycle and payable deferred period. The relationship between liquidity measurement variable and profitability measurement variables were not statistically significant and there was no relationship between cash conversion cycle and leverage ratio.

Mukhopadhyay (2004) stated that firms would be constrained to smoothly run the day to day operations if there were negative working capital and also difficult to settle short term obligations. Singh (2004) explained that, the liquidity position of any firm mainly could depend on accounts receivable collection and payables deferred policy as well as inventories conversion period of firms. Kim et al. (1998) examined the determinants of corporate liquidity of 915 US industrial. They found that firms with large market to book ratio had significantly larger position in liquid assets. In addition, firm size tends to be negatively related to liquidity. Mehar (2001) studied the impact of equity financing on liquidity of 225 firms listed in Karachi stock exchange and reported that equity and fixed assets had positive relationship with working capital, in the long term. However, the liquidity position could be deteriorated with the increase in paid up capital. Hsiao and Tahmiscioglu (1997) reported that liquidity could be affected by substantial differences across firms in their investment behavior and firms characteristics. Enyi (2005) studied the relative solvency level of 25 sample firms and reported that, the firms with adequate working capital associated with their operational size had performed better than firms which had less working capital in terms of their operational size.

Bhunia (2007) studied liquidity management of public sector Iron and Steel enterprise in India. He found that the actual values of working capital lower than the estimated value of working capital for both companies under study and poor liquidity position in case of both companies. Izadinia and Taki (2010) examined the effects of working capital management on capability of profitability for listed firms on Tehran Stock Exchange. The results indicated that there was a negative significant relationship between cash conversion cycle and return on assets and significant amount of investment in inventories and accounts receivable leads to declining of profitability.

Mohmmadi (2009) examined the effect of working capital management on profitability for listed companies on Tehran Stock Exchange. He reported that there was a negative relationship between number of days accounts of days accounts receivable, number of days inventories, member of days accounts payable, cash conversion cycle and profitability. Yaaqobnejad et al. (2010) examined the relationship between working capital management and profitability. They reported that there was a negative relationship between variables of working capital management and profitability. In addition, the results indicated that increase in number of days accounts receivable, number of days accounts payable, number of days inventories and cash conversion cycle could lead to decrease in profitability of companies. Soenen and shin (1993) investigated the relationship between measure of the cash conversion cycle and corporate profitability for a large sample of listed American firms for the 1975-1994 period. They found a strong negative relation. This result indicated that managers could create value for their shareholders by reducing the cash conversion cycle to a reasonable minimum.

Samiloglu and Demirgunes (2008) examined the effect of working capital management on profitability for a sample of Turkish companies and reported that accounts receivables period, inventory period and leverage could influence on firm's profitability negatively; while growth (in sales) could influence on firm's profitability, positively. Smith (1980) conducted a study on profitability and liquidity and suggested that working capital management could directly influence the risk and the profitability of a firm. Hence, it can be inferred that effective working capital management could increase the financial strength of a business. Soenen (1993) also performed an analysis of working capital management and its relationship with financial performance. His study was based on US firms and suggested that if the length of net trade cycle could increase then it could 
affect the return on investment negatively. Jose et al. (1996) carried out a detailed analysis on the association of cash conversion cycle and financial returns. They located an inverse association of profitability with cash conversion cycle. Mallik et al. (2005) evaluated Indian pharmaceutical industry. They discovered that profitability and liquidity do not have any significant relationship for these firms. Meszek and Polewski (2006) analyzed the construction sector. Their work targeted mainly the strategies, which should be used for the working capital management in construction sector. Afza and Nazir (2007) studied 263 firms of Pakistan for a time phase of six years i.e. 19982003. They stated that adopting inefficient working capital management policies could influence on the profitability, negatively. Afza and Nazir (2008) estimated the effect of different types of working capital management policies on financial performance of firms in different sectors. They found an inverse relationship between degree of aggressiveness of these policies and profitability.

Uyar (2009) took a sample of 166 Turkish companies to predict the nature of relationship of profitability and size of the firms with Cash Conversion cycle. The result showed that profitability and size of the firms both were negatively associated with Cash Conversion Cycle. Mohamad and Saad (2010) stated that there was an inverse relationship between different working capital components and performance of firms listed on Malysian firms. Raheman et al. (2010) studied 204 manufacturing firms of Pakistan to explore the impact of working capital management on the performance of a firm. Results of their study demonstrated that performance of firms was significantly associated with cash conversion cycle and average age of inventory. They also described that Pakistani firms normally follow conservative policy for management of working capital i.e. they prefer to place more capital in liquid assets to avoid the risks of less availability of funds for daily operations.

Dănuleţiu (2010) assessed the effect of working capital management efficiency on the financial performance on Alba country corporations. He concluded that profitability had an inverse relationship with working capital management components. Gill et al. (2010) studied the relationship of profitability with working capital management of 88 companies of New York. They stated that if the collection period of accounts receivable were greater, then there would be less profitability. ul Haq et al. (2011) studied the relation between working capital with financial performance Pakistan corporations. They stated that a moderate relationship existed between financial performance and working capital management. Singh and Asress (2011) examined the effect of working capital solvency level on profitability by their study on Indian manufacturing firms. They reported that if a firm could have adequate amount of capital for its current operations, its performance would be better as compared with the firms having lower amount of working capital. Therefore, they suggested that availability of sufficient amount of working capital had positive impacts on the profitability of a firm as it enables a firm to manage all the current operating activities without any interruption.

\section{Research Hypothesis}

The present research is in accordance with the following major assumption:

There is a relationship between capital in flow management and gaining profit in research perspective. In addition, there are other assumption as follows:

1. There is a relationship between debt collection and operating profit.

2. There is a relationship between operating profit and the flow of good.

3 . There is a relationship between cash conversion cycle and operating profit.

4. There is a relationship between debt term and operating profit. 


\section{Research approach}

This research is practical as it was intended to contribute to decision making process and conducted based on reasonable theories and approaches. This research uses a random sample and the research design is data post event as it uses applied historical data. The statistic sample is Iranian stock market firms that are not financial or investment broker. The study selected 68 firms over the period $2008-$ 2013 for investigation as a random sample. SPSS software and required statistic approaches have been utilized to analyze data in this research:

1. Descriptive methods such as the average parameters, SD, regression and elongation factors are used to describe research variables

2. Hypothesis testing: like Kolmogorov test to analyze the normalization of variables distribution as default for using parametric approaches.

3. combined linear regression to determine the relation between independent and dependent variables.

4. Fisher test to extend the relationship between variables to statistic society.

The model research was defined as a mathematical relation as following:

$Y=f(N O P, A C P T, I T I D, C C C, A P P)$

where $Y$ is a dependent variable and the other ones are independent. In this research, this variable was named NOP. The independent variables are as follows,

NOP $=$ Operational Profit

ACP $=$ Receivable Accounts Period $=($ Accounts Receivable $/$ Daily Sales $)$

ITID $=$ Inventories Flow $=$ Net Sales $/$ Inventories

$\mathrm{CCC}=$ Operation Cycle

APP $=$ Debit Payment Period $=($ Accounts Payable $/$ Daily Purchase $)$

Therefor relationship between dependent and in-dependents variables was defined as a linear parametric equation as following:

$N O P_{i t}=\beta_{0}+\beta_{1}\left(A C P_{i t}\right)+\beta_{2}\left(I T I D_{i t}\right)+\beta_{3}\left(C C C_{i t}\right)+\beta_{4}\left(A P P_{i t}\right)$

$\beta_{0}, \beta_{1}, \beta_{2}$ and $\beta_{3}$ are unknown parameters and assessed based on combined linear regression and Least squares technique. Other ones are practical variables, which participate in sample according to firms performances.

\section{Research findings}

In this section, first, the summary of description founding is explained. Next, because of the use of multi-variable linear-regression, its preliminaries are evaluated. Finally, the relationship between variables is estimated. Table 1 shows a brief explanation of findings description.

\section{Table 1}

\section{Descriptive statistic of variables}

\begin{tabular}{|c|c|c|c|c|c|c|}
\hline Variable & Mean & St. Deviation & Minimum & Maximum & Skewedness & Kurtosis \\
\hline Operational Earning & 60.44 & 1.41 & 941.33 & 1.20 & 4.077 & 19.81 \\
\hline Cash Cycle & 31.44 & 3.29 & 200 & 10 & 1.82 & 5.10 \\
\hline Receivables Period & 13.34 & 4.18 & 300.54 & 23 & 15.18 & 28.18 \\
\hline Payables Period & 49.10 & 1.52 & 890.54 & 1.24 & 4.28 & 2915476 \\
\hline Inventory Flow Period & 15.99 & 3.45 & 346 & 1.42 & 7.03 & 420 \\
\hline
\end{tabular}


Based on similar and related research methodology, the relationship between of variables was estimated based on variables with multi-variables linear-regression. This method is defined based on some preliminaries such as normality of variables distribution, linear independency of dependents variable etc. A Kolmogorov's test is used to analyze Normal distribution of variables and the results are summarized in Table 2 as follows,

Table 2

The Summary of Kolmogorov's Test

\begin{tabular}{llllllll}
\hline Parameter & Mean & St. Deviation & Absolute & Positive & Negative & Statistic & Sig. Level \\
\hline Amount & 4.7289 & 6.9381 & 0.382 & 0.382 & -0.306 & 3.149 & 0.056 \\
\hline
\end{tabular}

As we can observe from the results of Table 2, the variable is normally distributed. We need to also investigate the linear relationship between independent variables including debt term, the flow of goods, debt collection is the other linear regression default. For analysis, Pearson linear regression assumption is used and the results are shown in Table 3.

Table 3

The linear independency analysis

\begin{tabular}{|c|c|c|c|c|c|}
\hline & & ITID & $\mathrm{ACP}$ & APP & $\mathrm{ccc}$ \\
\hline \multirow{3}{*}{ ITID } & Pearson Correlation & 1 & -.015 & -.021 & -.252 \\
\hline & Sig. (2-tailed) & & .000 & .000 & .000 \\
\hline & $\mathrm{N}$ & 68 & 68 & 68 & 24 \\
\hline \multirow{3}{*}{ ACP } & Pearson Correlation & -.015 & 1 & $.278^{*}$ & -.064 \\
\hline & Sig. (2-tailed) & .000 & & .000 & .000 \\
\hline & $\mathrm{N}$ & 68 & 68 & 68 & 24 \\
\hline \multirow{3}{*}{ APP } & Pearson Correlation & -.021 & $.278^{*}$ & 1 & -.189 \\
\hline & Sig. (2-tailed) & .000 & .000 & & .000 \\
\hline & $\mathrm{N}$ & 68 & 68 & 68 & 24 \\
\hline \multirow{3}{*}{$\mathrm{ccc}$} & Pearson Correlation & -.252 & -.064 & -.189 & 1 \\
\hline & Sig. (2-tailed) & .000 & .000 & .000 & \\
\hline & $\mathrm{N}$ & 24 & 24 & 24 & 24 \\
\hline
\end{tabular}

*. Correlation is significant at the 0.05 level (2-tailed).

According to above table, Pearson correlation factor and a meaningful level is determined. The linear correlation rate are shown in 2 ways. The upper number is correlation factor and the lower one is meaningful level. Linear Dependence of independent variables is the assumed condition of using linear regression. Some of correlations are near to 0 , which means the correlation between variables can be ignored. Fig. 1 shows that data are not following a regular pattern and the stability of the variance can be accepted. In addition, Table 4 demonstrates other information of the regression analysis.

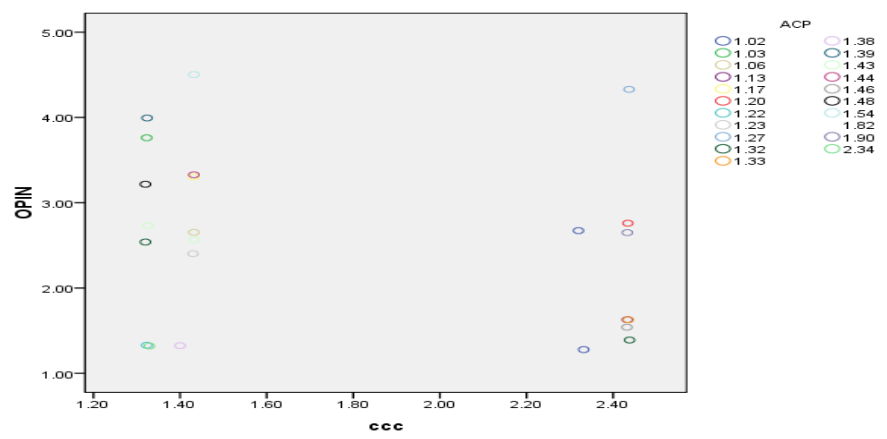

Fig. 6. Capital inflow and gaining profit dispersion 
Table 3

The Summary Normalization of remaining distribution

\begin{tabular}{cccc}
\hline R-Square & Adjusted R-Square & Std. Error of the Estimate & Durbin-Watson \\
\hline 0.102 & 0.087 & 1.03082 & 1.982 \\
\hline
\end{tabular}

As we can observe from the results of Table 3, Durbin-Watson is within an acceptable level and there is no auto-correlation between residuals. Finally, Table 4 demonstrates the results of our findings.

Table 4

The results of regression analysis

\begin{tabular}{lccccc}
\hline Variables & Parameter & St. Deviation & Adjusted & T-Statistic & Sig. Level \\
\hline Constant & 3.105 & 1.677 & 0.000 & 1.852 & 0.000 \\
Cash Cycle & -0.003 & 0.003 & -0.488 & 0.293 & 0.003 \\
Receivables Period & -0.749 & 0.749 & -0.346 & -0.202 & 0.042 \\
Payables Period & 1.244 & 1.244 & 0.172 & 0.735 & 0.071 \\
Inventory Flow Period & 0.440 & 0.440 & 0.209 & -0.893 & 0.045 \\
\hline
\end{tabular}

Based on the results of Table 4, it is showed that:

1) There is a reverse relation between dependent variable (operational earning) with cash cycle, receivable accounts period and inventory flow period. Because the estimated coefficients of these variables are negative.

2) There direct relation between dependent variable (operational earning) with payable accounts period. Because the estimated coefficients of this variable is positive.

3) Based on the estimated significance level, the estimated parameters are meaningful at 90 to 95 percent.

4) Based on Table 3, the R-Square and its adjusted amount are 0.102 and 0.087 and then the relation between operational earning and dependents variables is weak.

After substitution of estimated parameters on the mathematical equation, the relation between variables is defined as following:

NOPit=3.105+-0.003 (ACPit) + 0.749 (ITIDit) +1.244 (CCCit) +0.440 (APPit)

In addition, Table 5 demonstrates the results of ANOVA test.

\section{Table 5}

The Summary of Parametric ANOVA

\begin{tabular}{lccccc}
\hline Parameter & Sum of Squares & D. of Freedom & Mean Squares & F-Statistic & Sig. Level \\
\hline Between & 2.294 & 4 & 0.574 & --- & --- \\
Inter & 20.189 & 19 & 1.063 & --- & ---- \\
\hline Total & 22.414 & 23 & --- & 0.540 & 0.0215 \\
\hline
\end{tabular}

As we can observe from the results of Table 5, Fisher test significance level is 0.0215 and less than 5 percent. Therefore, the extrapolation of relation between variables is meaningful at 95 percent of confidence level. Therefore, there is a remarkable relation between independent and beneficiary variables so there is a weaker relation between debt collection and the flow of goods than cash and debt cycle. In our survey, the Pearson correlation ratio between receivable accounts periods and operational earning is equal to $r=-0.391$ with Sig. $=0.000$, which indicates a meaningful and reverse relationship. In addition, the Pearson correlation ratio between inventory flow period and operational earnings is equal to -0.237 with Sig. $=0.048$, which indicates the negative and significant 
relationship. Moreover, the Pearson correlation ratio between payable accounts period and operational earnings is equal to 0.432 with $\mathrm{Sig} .=0.015$, which means the relationship is positive and meaningful. Finally, the Pearson correlation ratio between cash cycle period and operational earnings is negative and equal to -0.137 with $\mathrm{Sig}$. $=0.012$, which means there was a reverse relationship between two variables.

\section{Conclusion}

In this research, 68 firms of Tehran Stock Exchange were chosen randomly and their financial performances were investigated over the period 2008-2013. The following are the summary of our findings,

1. There is an inverse relationship between dependent variable (operating Earning) and independent variables (Receivable Accounts Period, the Inventory flow Period and Cash cycle Period). In other word, if the Receivable Accounts Period, the Inventory flow Period and Cash cycle Period are increased, operating earnings is decreased.

2. There is direct relationship between operating earnings and Payable Accounts Period. In the other word, if the Payable Accounts Period is increased, Operating Earnings is increased.

3. The relation between Receivable Accounts Period, the Inventory flow Period, the Cash cycle Period and Payable Accounts Period with Operating Earnings is weak. Because the estimated RSquare and Pearson Correlation Coefficients are near to zero.

\section{References}

Afza, T., \& Nazir, M. S. (2007). Working capital management policies of firms: Empirical Evidence from Pakistan. Pakistan Journal of Commerce and Social Sciences, 2(2), 15-28.

Afza, T., \& Nazir, M. S. (2008). Working Capital Approaches and Firm's Returns in Pakistan. Pakistan Journal of Commerce and Social Sciences, 1(1), 25-36.

Amit, K., Mallik, D. S., \& Debdas, R. (2005). Working Capital and Profitability: A Study on Their Relationship with Reference to Selected Companies in Indian Pharmaceutical Industry. GITAM Journal of Management, 3(2), 51 - 62.

Bhunia, A. (2007). Liquidity management of public sector iron and steel enterprises in India.

Chowdhury, A., \& Amin, M. M. (2007). Working capital management practiced in Pharmaceutical companies in Dhaka stock, 4(2), 75-86

Dănuleţiu, A. E. (2010). Working capital management and profitability: A case of Alba county companies. Annales Universitatis Apulensis Series Oecon., 12 (1), 364-374.

Deloof, M. (2003). Does working capital management affect profitability of Belgian firms?. Journal of Business Finance \& Accounting, 30(3-4), 573-588.

Eljelly, A. M. (2004). Liquidity-profitability tradeoff: an empirical investigation in an emerging market. International Journal of Commerce and Management,14(2), 48-61.

Enyi, E. P. (2005). Applying Relative Solvency to Working Capital Management-The Break-Even Approach. Available at SSRN 744364.

Ganesan, V. (2007). An analysis of working capital management efficiency in telecommunication equipment industry. Rivier academic journal, 3(2), 1-10.

Gill, A., Biger, N., \& Mathur, N. (2010). The relationship between working capital management and profitability: evidence from The United States. Business and Economics Journal, 10, 1-9.

Hsiao, C., \& Tahmiscioglu, A. K. (1997). A panel analysis of liquidity constraints and firm investment. Journal of the American Statistical Association, 92(438), 455-465.

ul Haq, I., Sohail, M., Zaman, K., \& Alam, Z. (2011). The Relationship between Working Capital Management and Profitability: A Case Study of Cement Industry in Pakistan. Mediterranean Journal of Social Sciences, 2(2), 2039-2117. 
Izadinia, N., Taki, A. (2010). Examination the effects of working capital management an capability of profitability for listed companies on Tehran stock exchange. Journal -Financial Accounting Research, 5, 120 - 139.

Jose, M. L., Lancaster, C., \& Stevens, J. L. (1996). Corporate returns and cash conversion cycles. Journal of Economics and finance, 20(1), 33-46.

Kim, C. S., Mauer, D. C., \& Sherman, A. E. (1998). The determinants of corporate liquidity: Theory and evidence. Journal of financial and quantitative analysis, 33(03), 335-359.

Lazaridis, I., \& Tryfonidis, D. (2006). Relationship between working capital management and profitability of listed companies in the Athens stock exchange. Journal of financial management and analysis, 19(1), 26-35.

Lyroudi, K., \& Lazaridis, Y. (2000). The cash conversion cycle and liquidity analysis of the food industry in Greece.

Mallik, A., Sur, D., \& Debdas, R. (2005). Working capital and profitability: a study on their relationship with reference to selected companies in Indian pharmaceutical industry. GITAM Journal of Management, 3(2), 51-62.

Mehar, A. (2005). Impacts of equity financing on liquidity position of a firm. Applied Financial Economics, 15(6), 425-438.

Meszek, W., \& Polewski, M. (2006). Certain aspects of working capital in a construction company. Technological and Economic Development of Economy,12(3), 222-226.

Mohammadi, M. (2009). Effects of working capital management on companies' profitability of listed companies on Tehran stock exchange. Journal of management, 14, 80-91.

Mohamad, N. E. A. B., \& Saad, N. B. M. (2010). Working capital management: The effect of market valuation and profitability in Malaysia. International Journal of Business and Management, 5(11), p140.

Mukhopadhyay, D. (2004). Working capital management in heavy engineering firms-A case study. Management Accountant Calculation, 39, 317-323.

Raheman, A., \& Nasr, M. (2007). Working capital management and profitability-case of Pakistani firms. International review of business research papers, 3(1), 279-300.

Raheman, A., Afza, T., Qayyum, A., \& Bodla, M. A. (2010). Working capital management and corporate performance of manufacturing sector in Pakistan.International Research Journal of Finance and Economics, 47(1), 156-169.

Samiloglu, F., \& Demirgunes, K. (2008). The effect of working capital management on firm profitability: evidence from Turkey. The International Journal of Applied Economics and Finance, 2(1), 44-50.

Singh, K., \& Asress, F. C. (2011). Determining working capital solvency level and its effect on profitability in selected Indian manufacturing firms. International Journal of Research In Commerce, Economics And Management. [9] Lingesiya, Y and Nalini, S (2011) "Working Capital Management and Firms' Performance: An Analysis of Sri Lankan Manufacturing Companies" journal of ICBI.

Smith, K. (1980). Profitability versus liquidity tradeoffs in working capital management. Readings on the management of working capital, 549-562.

Soenen, L. A. (1993). Cash conversion cycle and corporate profitability. Journal of Cash Management, 13, 53-53.

Shin, H. H., \& Soenen, L. (1998). Efficiency of working capital management and corporate profitability. Financial practice and education, 8, 37-45.

Singh, P. K. (2004). Working capital management in Lupin laboratories Ltd.-A case study. Management Accountant Calcutta, 39(7), 534-541.

Sayaduzzaman, M. D. (2006). Working Capital Management: A Study on British American Tobacco Bangladesh Company Ltd. Journal of Nepalese Business Studies, 3(1), 78-84.

Uyar, A. (2009). The relationship of cash conversion cycle with firm size and profitability: an empirical investigation in Turkey. International Research Journal of Finance and Economics, 24(2), 186-193. 
Vishnani, S., \& Shah, B. K. (2007). Impact of Working Capital Management Policies on Corporate Performance-An Empirical Study. Global Business Review, 8(2), 267-281.

Yaaqobnejad, Ahmad, et al. (2010). The relationship between working capital management and profitability of listed companies an Tehran stock exchange. Journal of Financial engineering and portfolio management, 2, 117-137. 